\title{
XPS and Raman Characterized Lime Stabilized Lead Contaminated Soil
}

\author{
Mabrouk Hassan $^{1}$, Bubaker M Hamad Almansori ${ }^{2}$ \\ ${ }^{1}$ National Authority of sciences and Research technology - Tripoli-Libya. \\ ${ }^{2}$ Omar Almukthar university-Elbeda-Libya.
}

\section{ARTICLE INFO}

Keywords:

Raman, leaching, lead,

lime, stabilization. XPS

\begin{abstract}
Artificially lead $(\mathrm{Pb})$ contaminated soil was stabilised with hydrated lime and the leaching behaviour of the element was investigated. A 5 grams' sample of contaminated soil was thoroughly mixed with $0.1 \mathrm{~g}$ of lime, and The mixture containing $50 \mathrm{ml}$ of leaching solution was shaken for 2hours, and then the solution was filtered using a Whatman Grade 540. filter paper. The extent of lead leaching, with and without the addition of lime, was determined after adjusting the solution $\mathrm{pH}$ between (1-12). More than $90 \%$ of the lead was retained when the $\mathrm{pH}$ was 12.0 . Results from the analysis of X-ray photoelectron spectroscopy and Raman, on the soil samples retained on the filter paper showed the formation of lead sulphate, lead oxide and lead carbonate. which is in agreement with the analysis of X-ray diffraction and FTIR measurements.
\end{abstract}

\section{1- Introduction}

The use of stabilization/solidification technology for the immobilization of heavy metals in contaminated lands with various additives including cement, lime and fly ash has been reported [1], [2]. Mickney et al [3] reported that the use of lime in contaminated soil reduces the solubility of toxic metals and also reduces the moisture content of the soil. $\mathrm{Pb}$ is the most common contaminant in the environment and has chronic toxicity. Pb contamination has been found in 604 out of 1221 superfund sites on the National Priorities List (NPL). There have been intensive studies about $\mathrm{Pb}$ immobilization mechanisms in S/S-treated wastes [2]

The US Environmental Protection Agency(USEPA) recognizes cementitious solidification as the "best demonstrated available technology (BDAT)" for land disposal of most toxic elements. Alkaline matrices such as $\mathrm{Ca}(\mathrm{OH}) 2$ and cement are commonly used in waste conditioning because they are inexpensive, readily incorporate wet wastes and their alkalinity reduces the solubility of many inorganic toxic or hazardous metals

\footnotetext{
Corresponding Author E-Mail Address: mabr1_h@yahoo.co.uk
} 
Here we report on investigations in which hydrated lime has been used to stabilise lead contaminated soil.

\section{2-Materials and Methods}

The oxide composition of the uncontaminated soil and lime is presented in Table 1 . The water content of the soil was $13.49 \%$.

Table 1 The chemical composition (by mass\%) of the hydrated lime and uncontaminated soil used in these investigations.

\begin{tabular}{|c|c|c|c|c|c|c|c|c|c|c|c|c|c|c|}
\hline $\begin{array}{c}\text { Componen } \\
t\end{array}$ & $\begin{array}{l}\mathrm{Na} \\
{ }_{2} \mathrm{O}\end{array}$ & $\begin{array}{c}\mathrm{Mg} \\
\mathrm{O}\end{array}$ & $\begin{array}{l}\mathrm{Al}_{2} \\
\mathrm{O}_{3}\end{array}$ & $\begin{array}{l}\text { Si } \\
\mathbf{O}_{2}\end{array}$ & $\begin{array}{l}\mathbf{P}_{2} \\
\mathbf{O}_{5}\end{array}$ & $\begin{array}{l}\text { S } \\
\text { O } \\
3\end{array}$ & $\begin{array}{l}\mathbf{K} \\
2 \\
\mathbf{O}\end{array}$ & $\begin{array}{c}\text { Ca } \\
\mathbf{O}\end{array}$ & $\begin{array}{l}\mathbf{T i} \\
\mathbf{O}_{2}\end{array}$ & $\begin{array}{c}\mathrm{Mn}_{3} \\
\mathrm{O}_{4}\end{array}$ & $\begin{array}{c}\mathrm{Fe}_{2} \\
\mathrm{O}_{3}\end{array}$ & $\begin{array}{c}\mathbf{Z n} \\
\mathbf{O}\end{array}$ & $\begin{array}{l}\text { Sr } \\
\text { O }\end{array}$ & $\mathrm{BaO}$ \\
\hline $\begin{array}{l}\text { Hydrated } \\
\text { lime }\end{array}$ & $\begin{array}{c}0 . \\
13\end{array}$ & $\begin{array}{c}0.2 \\
2\end{array}$ & $\begin{array}{c}0.1 \\
3\end{array}$ & $\begin{array}{c}0 . \\
83\end{array}$ & $\begin{array}{c}0 . \\
04\end{array}$ & $\begin{array}{l}0 . \\
0 \\
9\end{array}$ & $\begin{array}{l}\mathrm{N} \\
\mathrm{D}\end{array}$ & $\begin{array}{l}60 \\
.1\end{array}$ & $\begin{array}{c}0 . \\
01\end{array}$ & 0.05 & $\begin{array}{c}0.0 \\
5\end{array}$ & $\begin{array}{c}0.0 \\
1\end{array}$ & $\begin{array}{l}0 . \\
07\end{array}$ & 0.01 \\
\hline $\begin{array}{l}\text { Uncontami } \\
\text { nated } \\
\text { soil }\end{array}$ & $\begin{array}{c}0 . \\
20\end{array}$ & $\begin{array}{c}0.1 \\
3\end{array}$ & $\begin{array}{c}2.8 \\
9\end{array}$ & $\begin{array}{c}93 \\
.6\end{array}$ & $\begin{array}{c}0 . \\
02\end{array}$ & $\begin{array}{l}0 . \\
0 \\
6\end{array}$ & $\begin{array}{l}1 . \\
7 \\
2\end{array}$ & $\begin{array}{l}0 . \\
12\end{array}$ & $\begin{array}{c}0 . \\
08\end{array}$ & 0.01 & $\begin{array}{c}0.6 \\
5\end{array}$ & $\begin{array}{c}0.0 \\
1\end{array}$ & $\begin{array}{l}\mathrm{N} \\
\mathrm{D}\end{array}$ & 0.03 \\
\hline
\end{tabular}

The soil was synthetically contaminated by adding litre of solution containing $1000 \mathrm{mg} / \mathrm{l} \mathrm{of} \mathrm{Pb}$ prepared from $\mathrm{Pb}\left(\mathrm{NO}_{3}\right)_{2}$, to $0.5 \mathrm{~kg}$ of soil in $2 \mathrm{~L}$ flask.

The mixture was shaken for $24 \mathrm{~h}$, until equilibrium is reached. The supernatant was discarded, and the soil was dried in an oven at $40{ }^{\circ} \mathrm{C}$ for $72 \mathrm{hrs}$ before use. The leaching test was implemented and the lead in the final leachate were filtered and measured by the ICP see Hassan et al [4].

The total digestion test was conducted in $1 \mathrm{~g}$ of contaminated soil with $5 \mathrm{ml}$ of $\mathrm{HNO}_{3}$, and $50 \mathrm{ml}$ of water for 10min duration on a hotplate, where the maximum extraction of $\mathrm{Pb}$ was achieved. The properties of the contaminated and non-contaminated soil are given in Table 2.

Table 2 Properties of the soils

\begin{tabular}{|c|c|c|}
\hline Parameters' & Uncontaminated soil & Contaminated soil \\
\hline $\mathrm{pH}$ & 6.94 & 5.65 \\
particle size & $5 \mathrm{~mm}$ & $4 \mathrm{~mm}$ \\
water content \% & $13.49 \%$ & $1.5 \%$ \\
lead in $\mu \mathrm{g} / \mathrm{g}$ & $<0.004$ & $791 \mu \mathrm{g} / \mathrm{g}$ \\
\hline
\end{tabular}


Whilst taking the measurements using Raman instrumentation it was considered in this study to increase the concentration of lead in the soils or as solution to $20,000 \mathrm{mg} / \mathrm{l}$ in order to enable the Raman instrument to detect the lead in the samples.

Raman microscopy was carried out using the Renishaw RM1000 NIR system working range at $785 \mathrm{~nm}$ wavelength. The following parameters were used in order to collect data from the samples: x 50 objective, 40 second scan time, $100 \%$ laser power.

Prior to analysis, the Raman instrument was calibrated using a silicon wafer, a spectrum of the silicon was collected in static mode with a 1 second scan time, using $100 \%$ laser power. Grams software was used to collect the spectra.

XPS measurements were made on a KRATOS AXIS 165 Ultra Photoelectron Spectrometer operated at $10 \mathrm{KV}$ and $15 \mathrm{~mA}$ using the $\mathrm{Al} \mathrm{K}$ (alpha) X-ray source (1486.6 eV). The takeoff angle was fixed at 90 degrees. The area corresponding to each acquisition was $400 \mu \mathrm{m}$ in diameter. Each analysis consisted on a wide survey scan (pass energy $160 \mathrm{eV}, 1.0 \mathrm{eV}$ step size) and highresolution scan (pass energy $20 \mathrm{eV}, 0.1 \mathrm{eV}$ step size) for $\mathrm{Pb}$. The binding energies of the peaks were determined using the $\mathrm{C} 1 \mathrm{~s}$ peak at $284.5 \mathrm{eV}$. The software Casa XPS 2.3.12 was used to fit the XPS spectra peaks.

\section{3-Results and Discussion}

\section{3-1 Raman Spectroscopic Analysis}

Raman spectroscopy is sensitive to the presence of calcium carbonate; it thus offers a ready assessment of the extent of its presence in the samples and is a useful technique for finger-printing of the material. This is seen by comparing the two curves at uncontaminated soil spectra with lead contaminated soil spectra or lead contaminated soils and lime treated soils or lead contaminated solution and treated lead solution spectra, the procedure of conducting the measurement are described section two.

In Figure 1 the peak at $1045 \mathrm{~cm}^{-1}$ show the presence of lead in the contaminated soils, spectra in B line, peak at $1045 \mathrm{~cm}^{-1}$ belongs to lead contaminated soils, since it is not present in blank soils. The soils were contaminated with $20,000 \mathrm{mg} / \mathrm{l}$ of lead solution in order to enable the Raman instrumental to detect the lead in the samples, as it had low detection limit.

In Figure 2, lime treated lead contaminated soil, not many peaks were observed by Raman, this may be attributed to curing effects, that it was not physical binding between the contaminated soils and the lime stabilizer. The only peak is at $455 \mathrm{~cm}^{-1}$ which was, present also in contaminated soils, there is only a small peak under close to $200 \mathrm{~cm}^{-1}$ which it might be attributed to $\mathrm{Ca}-\mathrm{O}$ vibration, according to Kirk.et al [1997] that would suggest presence of $\mathrm{Pb}-\mathrm{CaO}$.

In Figure 3, for $0.1 \mathrm{~g}$ lime in $50 \mathrm{ml}$ of deionised water, the other with $0.1 \mathrm{~g}$ of lime added to lead solution. This is seen by comparing the two curves in Figure 3, the one for lime in a solution of de-ionised water The lead solution was $20000 \mathrm{mg} / \mathrm{l}$ to enable the Raman to detect the lead in the samples. (see figure 3). 
The main peaks in stabilized solutions (see Fig.3) are 390, 701, $1045 \mathrm{~cm}^{-1}$, which is According to [Kirkpatrick. and Yarger.1997], (see Table 3), is assigned to Ca-O, symmetrical stretching of silicate tetrahedral carbonate group) and silicate groups.

Those peaks are referred to lead formation in treated samples, which can be referred to $\mathrm{Pb}-\mathrm{Ca}-\mathrm{O}$ or $\mathrm{Pb}_{-} \mathrm{SO}_{3}, \mathrm{~Pb}-\mathrm{Ca}-\mathrm{SO}_{4}$ which are the same compounds confirmed by other techniques' FTIR, and XRD. see Hassan et al 2013. in Figure 4.7 shows very similar peaks, except at $1000-1050 \mathrm{~cm}^{-1}$, where the contaminated soil sample shows a strong peak, which is due to the lead silicate carbonate group [ Kirkpatrick and Yarger.1997] also according to Gibbs et al [2010] it is $2 \mathrm{PbCO} 3 . \mathrm{Pb}(\mathrm{OH})_{2}$. The lead had reacted with the silica and carbonate present in the soil. The $v_{1}$ and $v_{4}$ vibrations of the carbonate were observed at $1084 \mathrm{~cm}^{-1}$ and $712 \mathrm{~cm}^{-1}$ respectively, and the lattice vibration at $280 \mathrm{~cm}^{-1}$ is due to $\mathrm{Ca}-\mathrm{O}$.

Figure 1 Raman spectra on lead contaminated soil, (A)-uncontaminated soil, (B)-lead contaminated soil

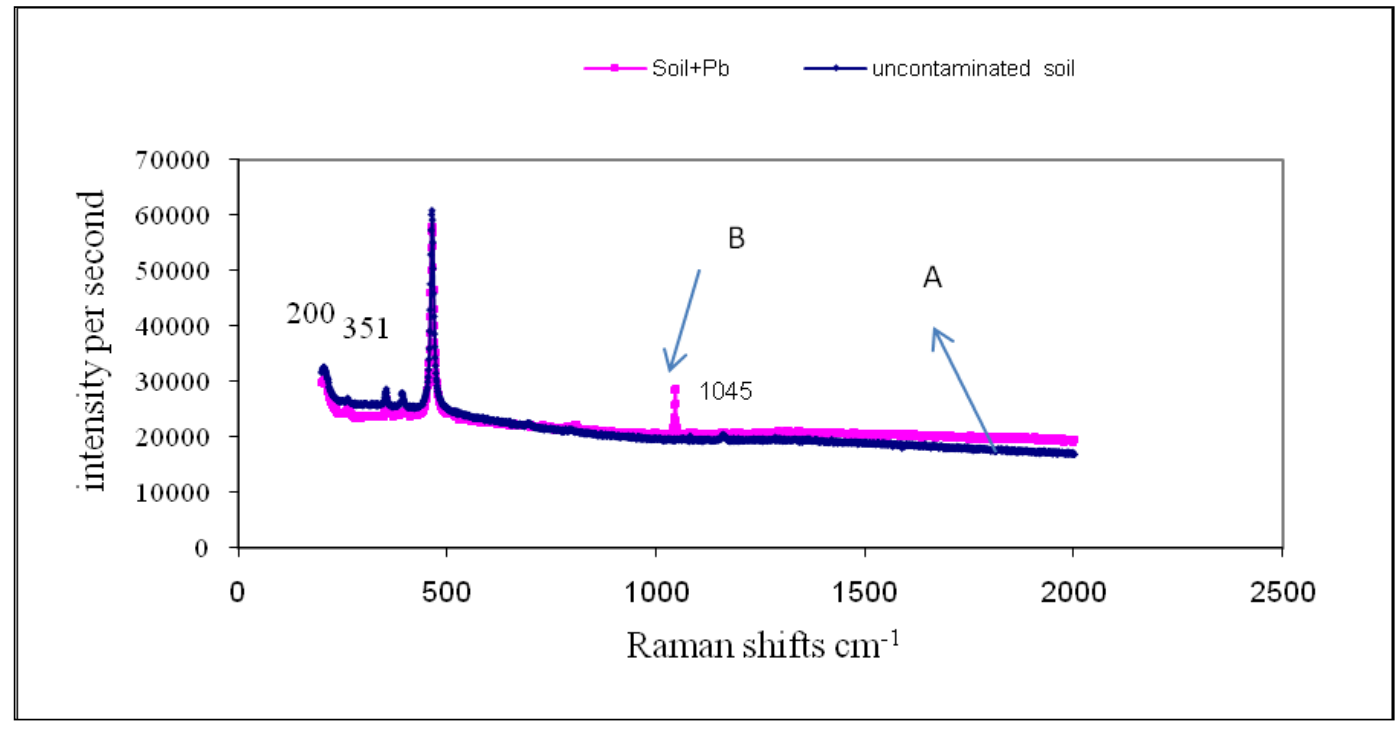

Figure 2 Raman spectra on lead contaminated soil and Lime treated soil, (A) .Lime treated contaminated soils, $\boldsymbol{( B ) . l e a d ~ c o n t a m i n a t e d ~ s o i l s ~}$ 


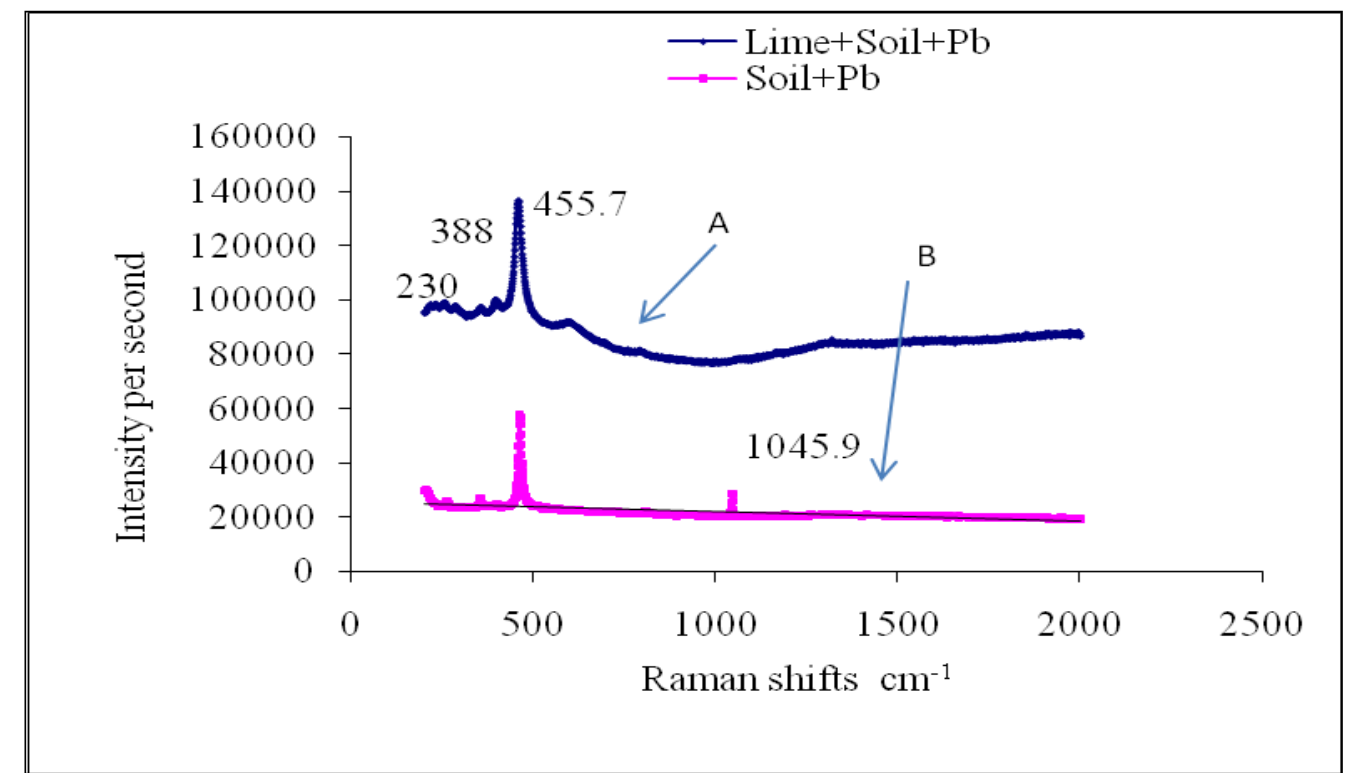

Figure 3 Raman spectra on Lime stabilized lead solution, (A)- blank lime, $1 \mathrm{~g}$ of lime in 50ml of deionised water $(B)-0.1 \mathrm{~g}$ of lime stabilized $\mathrm{Pb}$ solution

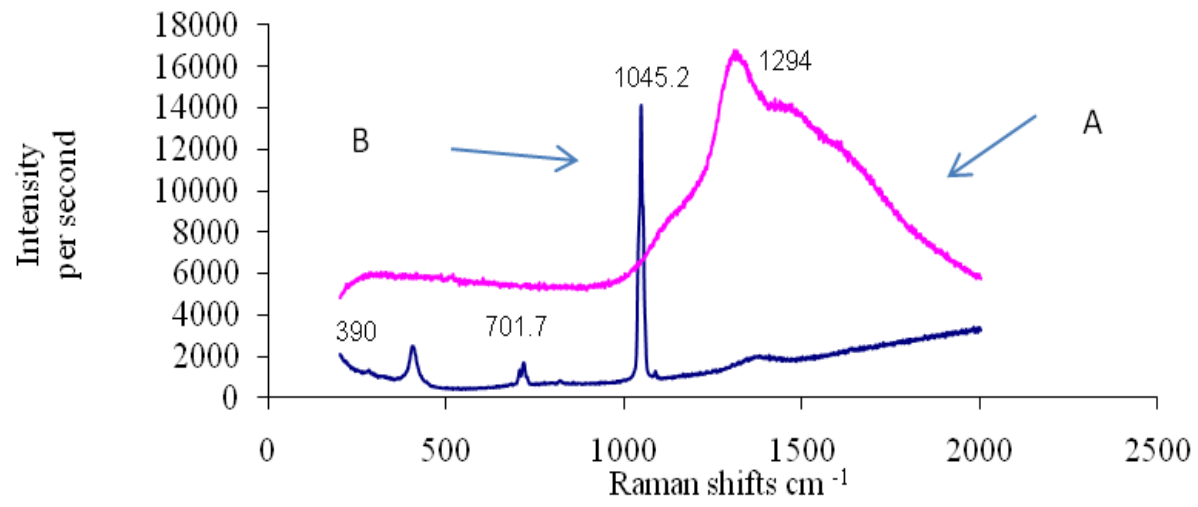


Table 3 Raman frequencies of the principle band in hydrate Portland cement [after KirkPatrick 1997] compared with results in this study

\begin{tabular}{|c|c|c|c|}
\hline $\begin{array}{l}\text { Band } \\
\mathrm{Cm}^{-1}\end{array}$ & Origin & $\begin{array}{l}\text { Lead contaminated } \\
\text { soil treated with lime } \\
\text { in this study }\end{array}$ & $\begin{array}{l}\text { Lime stabilized Pb } \\
\text { Solution in this study }\end{array}$ \\
\hline $200-400$ & Ca-O vibration & 351 & 390 \\
\hline $430-540$ & $\begin{array}{c}\text { Internal deformations of Si-O, } \\
\text { tetrahedra (O-si-Obending) }\end{array}$ & 455.7 & \\
\hline $600-700$ & silicate Group & & 701.7 \\
\hline $800-1100$ & $\begin{array}{l}\text { symmetrical stretching of silicate } \\
\text { tetrahedral carbonate group) } \\
\text { Symmetrical stretching (SS) of Si- } \\
\text { O tetrahedral. }\end{array}$ & 1045.9 & 1045 \\
\hline $\begin{array}{l}3000- \\
4000\end{array}$ & $\mathrm{OH}$ vibration & & \\
\hline
\end{tabular}

\section{3-2.1 XPS investigation for lead contaminated solution}

The XPS provides extra powerful information on characterisation the samples of lime treated lead solution. In Fig.4 a wide scan of XPS spectra on blank lime with deionised water shows no lead peaks in the spectra and demonstrates the elements that make the lime which are $\mathrm{Ca}, \mathrm{K}, \mathrm{O}$ in comparison with a wide scan of XPS for lime stabilised lead solution (see Fig.5).

In this spectra the $\mathrm{Pb} 4 \mathrm{f}$ were clearly presented in the specimen and positioned at $138 \mathrm{eV}$, which is only attributed to $\mathrm{Pb} 4 \mathrm{f}$.

In comparing with spectra of blank lime in Fig 4. the amount of $\mathrm{Ca}$ was higher due to none lead in blank lime. The explanation of low $\mathrm{Ca} 2 \mathrm{p}$ in $\mathrm{Fig} \mathrm{5}$, is the replacement of $\mathrm{Pb}$ ion to $\mathrm{Ca}$ ion which is attributed to ion exchange reaction between the $\mathrm{Ca}$ and $\mathrm{Pb}$ in presence of water. However, according to the XPS spectra standard database, which generally provide sufficient data for the determination of chemical states for uncomplicated (i.e. single peak) spectra, the main formation of lead compounds $\mathrm{Pb} 4 \mathrm{f}$ are given to $\mathrm{PbCO}_{3}$ and $\mathrm{PbO}$, see Fig.6. However, according to James et al [2008]. The binding energy at $138 \mathrm{eV}$ and the doublet $141 \mathrm{eV}$ are assigned to $\mathrm{PbO}$, or $\mathrm{Pb} \mathrm{SO}_{3}$.

The FTIR and XRD are in supporting of these results, see Hassan et al 20013.

In addition, Daeik et al [2009] observed that $\mathrm{Pb} 4 \mathrm{f}_{7 / 2}$ and 5/2 doublet were observed at 140 and $145 \mathrm{eV}$ and insufficient to distinguish $\mathrm{PbO}$ from $\mathrm{PbO}_{2}$ or $\mathrm{PbSO}_{3}$, or even $\mathrm{PbSO}_{4}$ and concluded that the survey scan is sufficient to distinguish metallic lead from the oxidized forms . 
Figure 4. Wide scan of XPS spectra of lime blank (deionised water and lime)

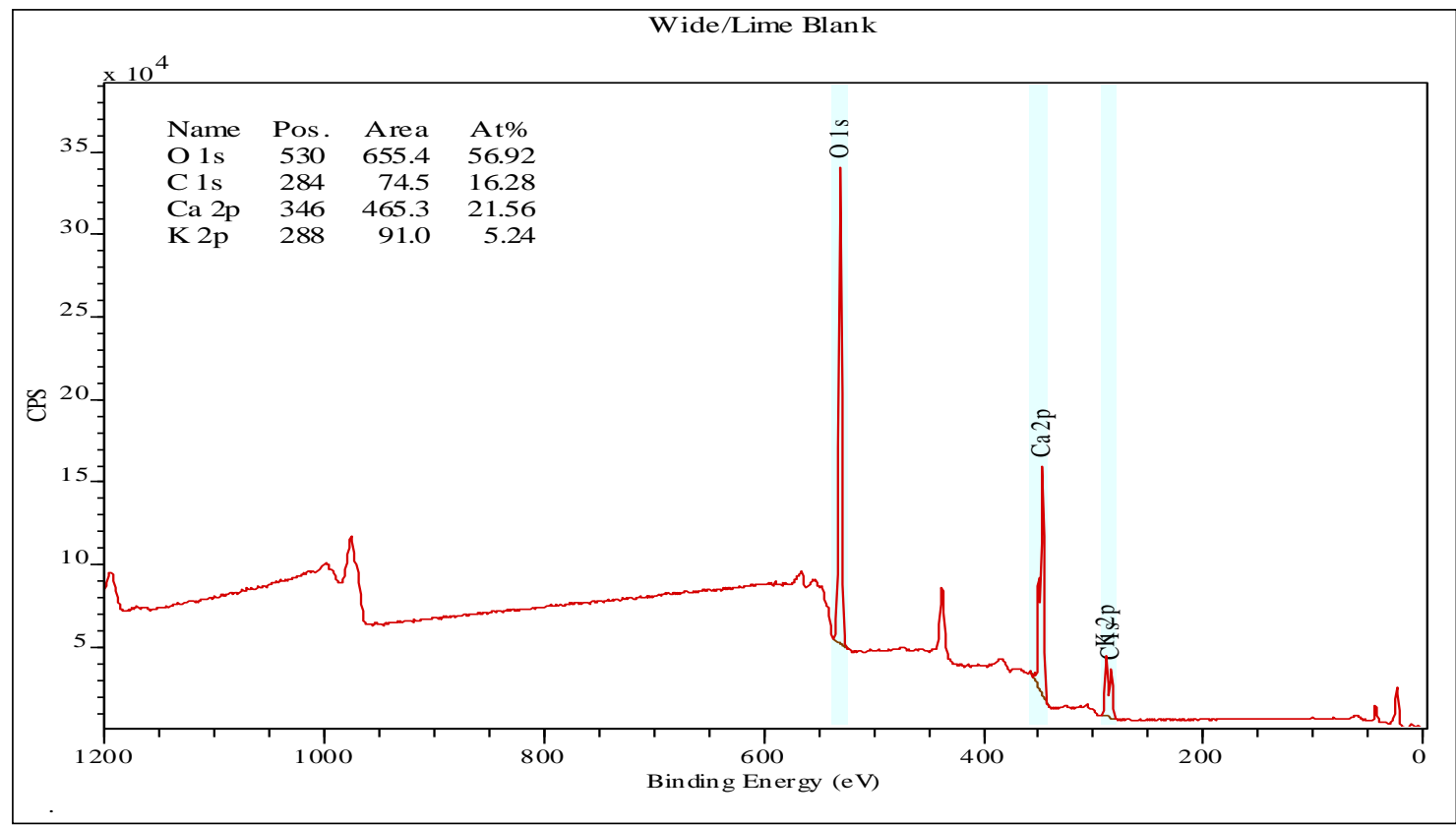

Figure 5 XPS wide scan spectra for $0.1 \mathrm{~g}$ of lime stabilized $50 \mathrm{ml}$ of 20,000 mg/lead solution

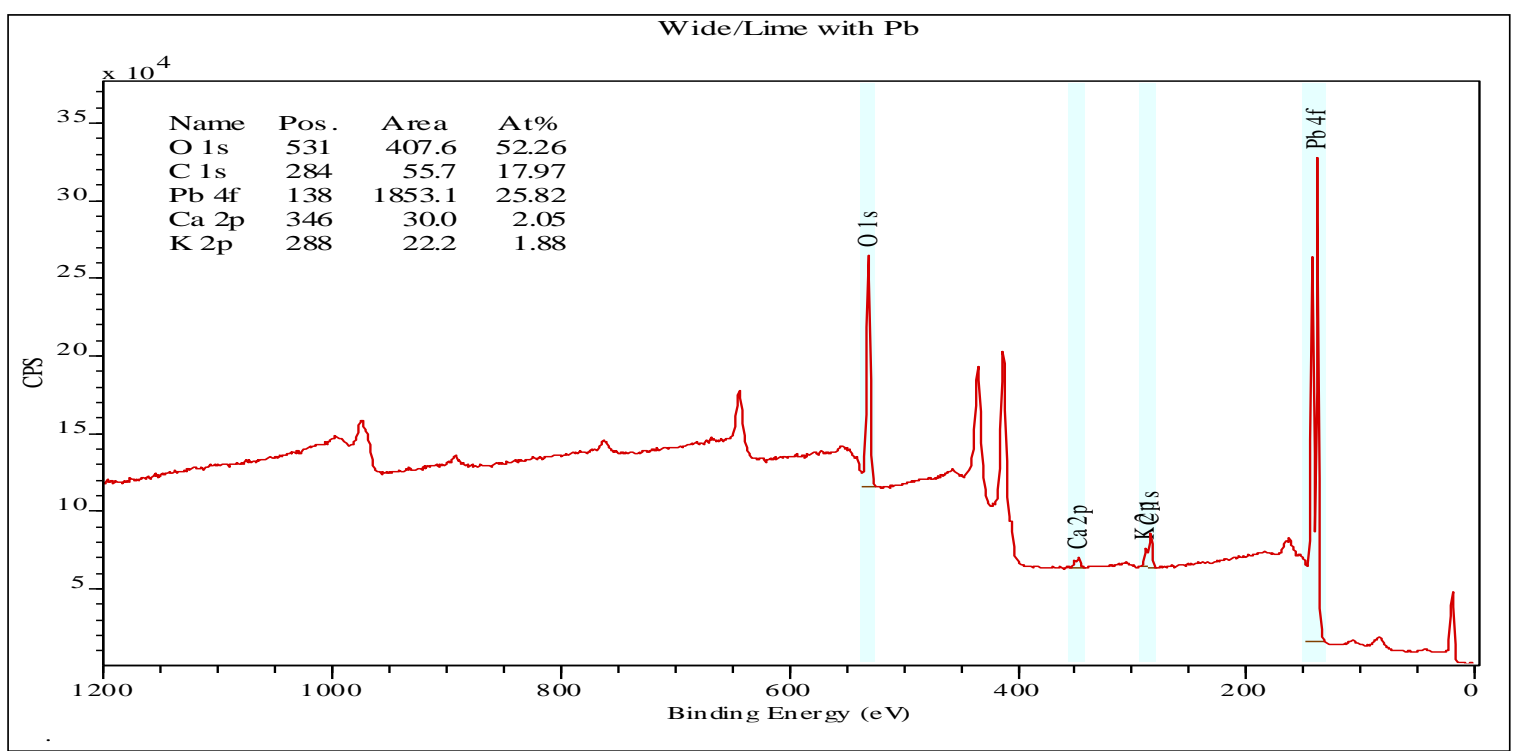


Figure 6 Detailed XPS analysis of the spectrum for lime treated lead contaminated solution, over the region of the lead $4 f$ spectral line

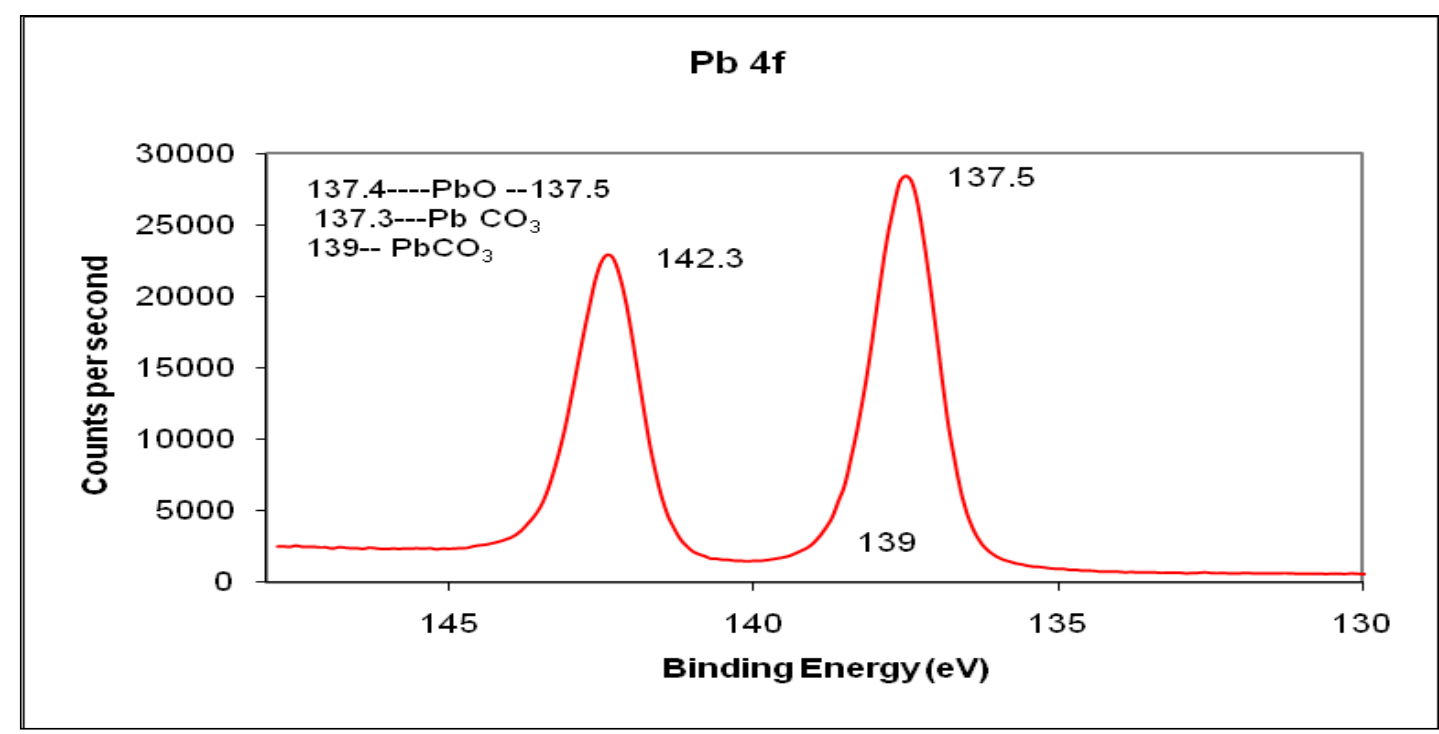

\section{3-2.2 XPS investigation of lead contaminated soils and treated soils}

Figure 7 presents a wide scan of lead contaminated soil; it shows clearly the position of lead $\mathrm{Pb} 4 \mathrm{f}$ at binding energy peak $136 \mathrm{eV}$, occupied about 0.91 . The majority of elements were $\mathrm{O} 1 \mathrm{~s}$, $\mathrm{Si} 2 \mathrm{p}$, and Na1s, which occupied 55, 20 and $4 \%$, respectively. While Ca2p only accounts for 1.18 $\%$. (see Figure 8 and 9).

However, the peaks $136 \mathrm{eV}$ are assigned to Pb4f7 according to XPS international data base, and $141 \mathrm{eV}$ is assigned to $\mathrm{Pb} 4 \mathrm{f} 5$. In classification to the chemical state for those peaks and relaying to James,.et al [2008] and [Tyczkowski and Pietrzyk.1998] the $137 \mathrm{eV}$ and the doublet $141 \mathrm{eV}$ are assigned to $\mathrm{PbO}, \mathrm{PbO}_{2}$ or $\mathrm{PbSO}_{3}$.

Similarly, Fig. 10 shows the wide scan of contaminated soil treated with $0.1 \mathrm{~g}$ lime, compared with untreated sample (see Fig, 8).

The $\mathrm{Pb}$ occupied $0.55 \%$ reduced from $0.91 \%$ in untreated soil. Ca2p occupied $0.50 \%$ and Si to $23 \%$ from $20.14 \%$ in untreated samples, the $\mathrm{Pb} 4 \mathrm{f}$ at doublet peaks 136.5 and 141.3 (see Fig.11), however in regard to James et al [2008] these peaks are assigned to $\mathrm{PbSO}_{3}$ and $\mathrm{PbSO}_{4}$.

Also many other compounds of lead are present (see Fig. 11) which are in agreement with the results obtained by XRD and FTIR. (See Hassan et al 2013). The multi-peaks in Fig.11 shows that many compounds were formed in the region of $\mathrm{Pb} 4 \mathrm{f}$, those compounds are for $\mathrm{Pb}$ at the region of $\mathrm{BE}$ from $138.2 \mathrm{eV}$ to $144 \mathrm{eV}$, such as $\mathrm{Pb} 4 \mathrm{f}_{7 / 21}$ and $\mathrm{Pb} 4 \mathrm{f}_{5 / 21}, \mathrm{~Pb}_{4} \mathrm{f}_{7 / 22}$ and $\mathrm{Pb} 4 \mathrm{f}_{5 / 22}$ 
Figure 7 Wide scan of XPS spectra of lead contaminated soil

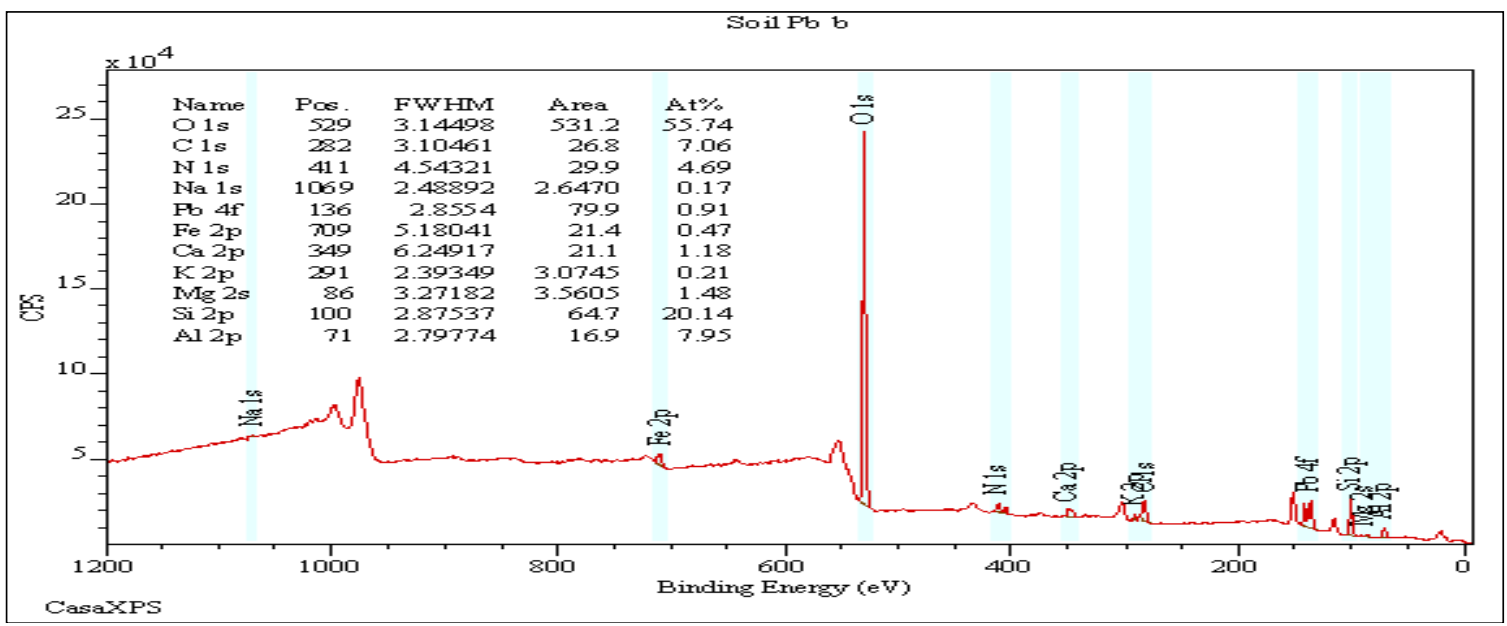

Figure 8 Detailed XPS analysis of the spectrum for lead contaminated soil, over the region of the lead $4 f$ spectral line

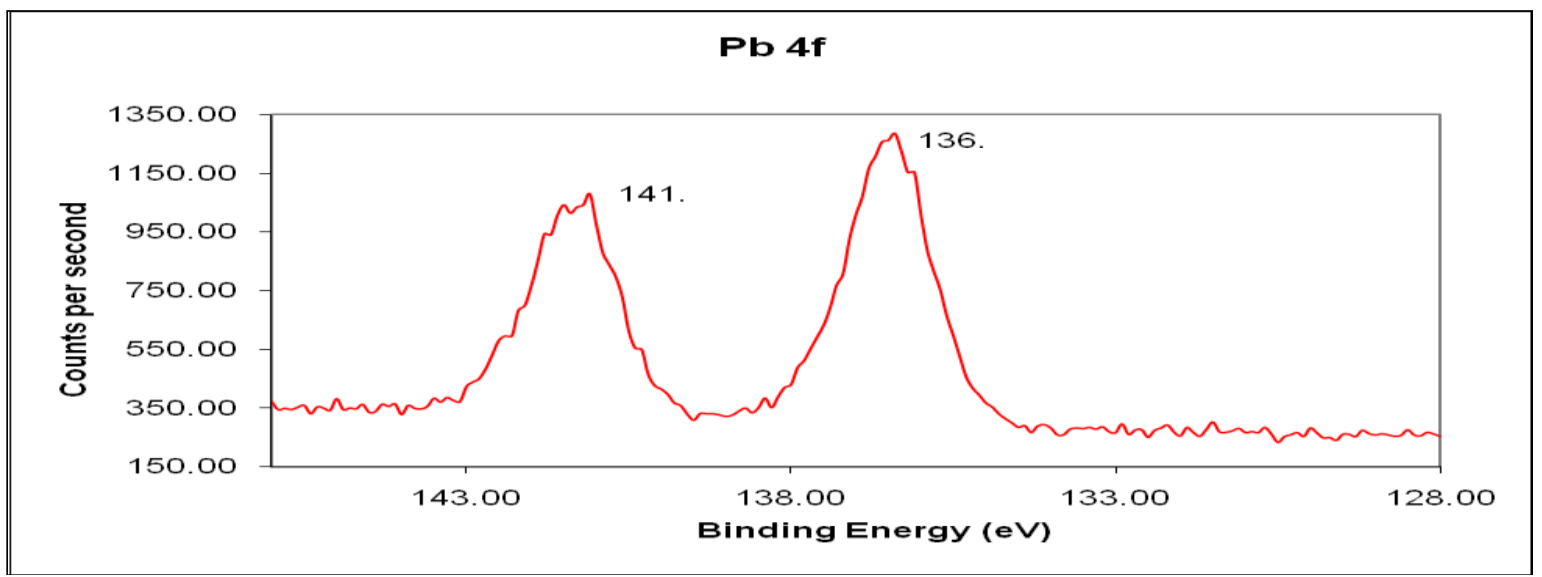


Figure 9 Wide scan of XPS spectra of $0.1 \mathrm{~g}$ of lime a stabilized $5 \mathrm{~g}$ of Pb contaminated soil, leached with $50 \mathrm{ml}$ of deionised water

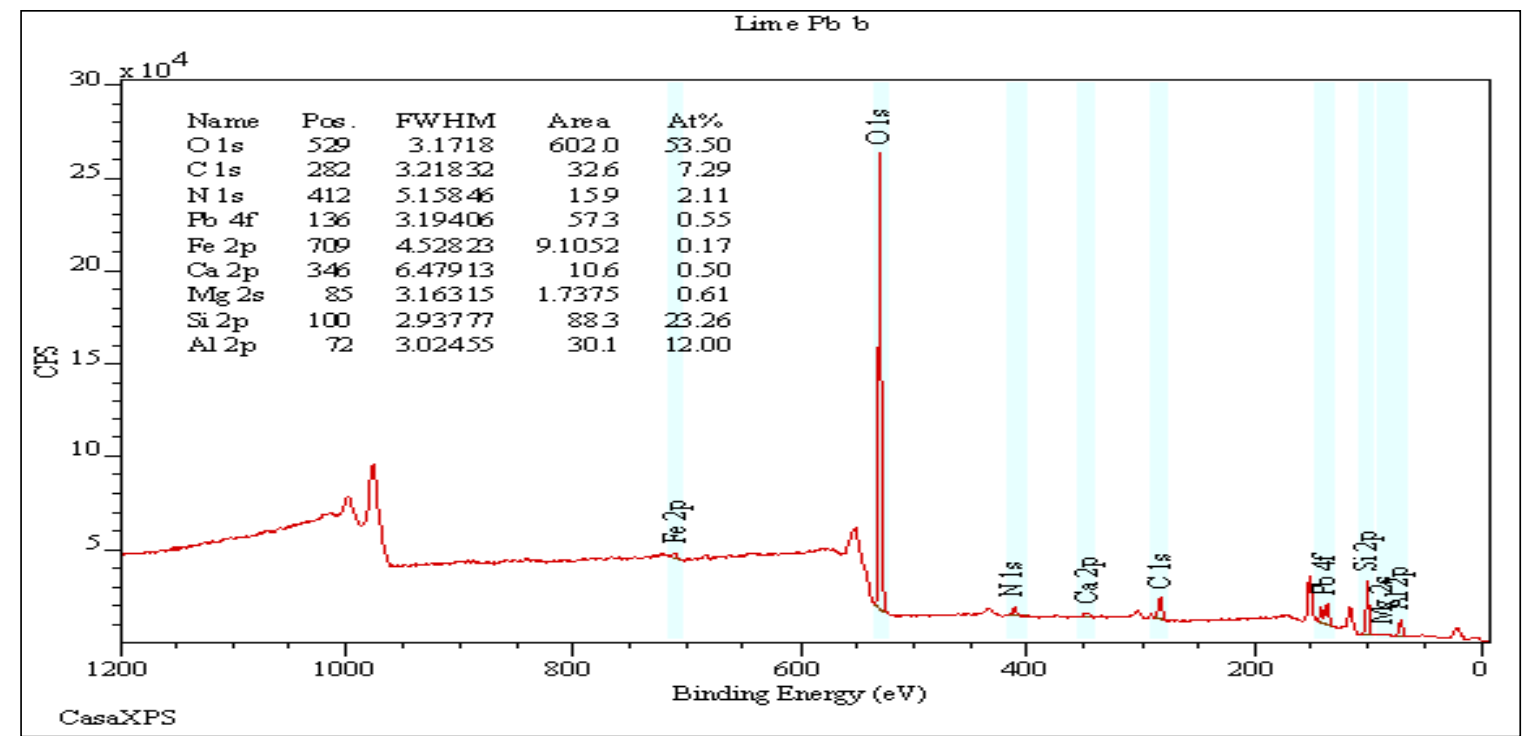

Figure 10 Detailed XPS analysis of the spectrum for lime treated lead contaminated soil, over the region of the lead $4 f$ spectral line

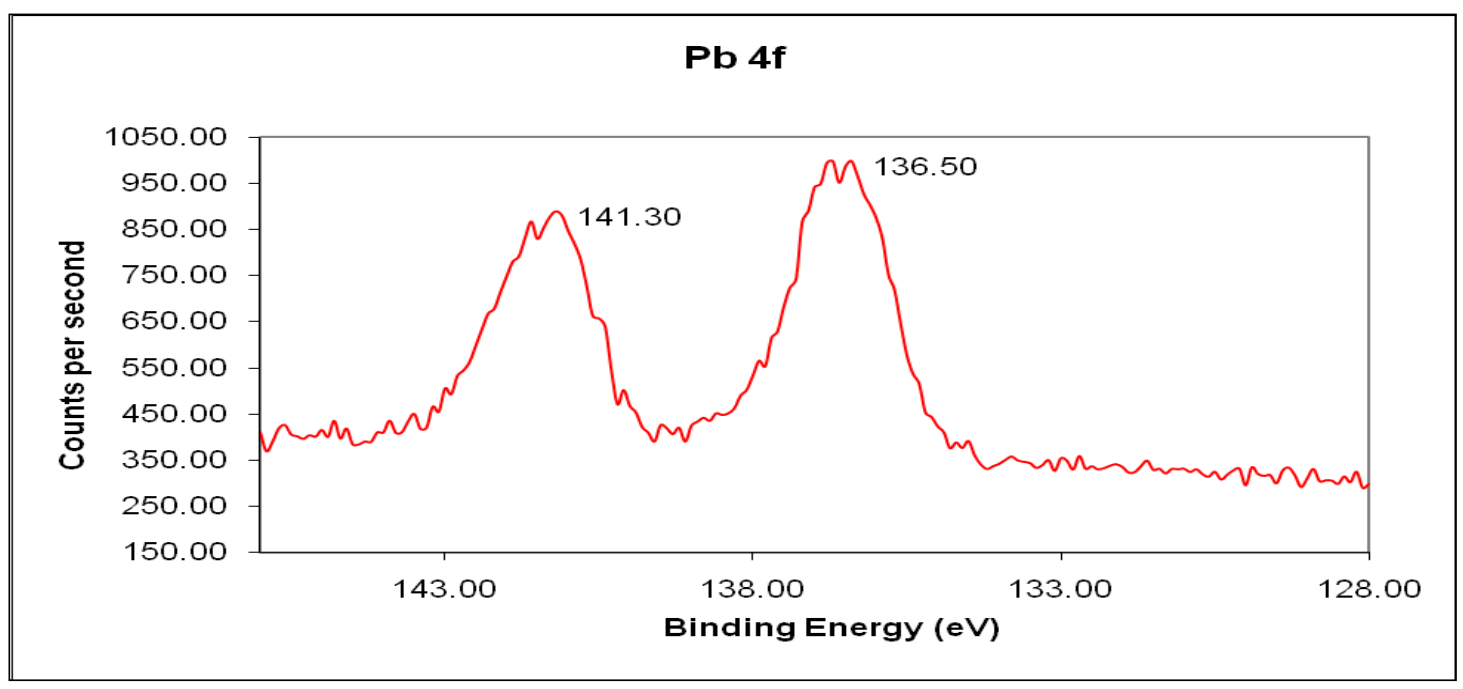


Figure 11 Detailed XPS analysis of the spectrum for lime treated lead contaminated soil, over the region of the lead 4 spectral line

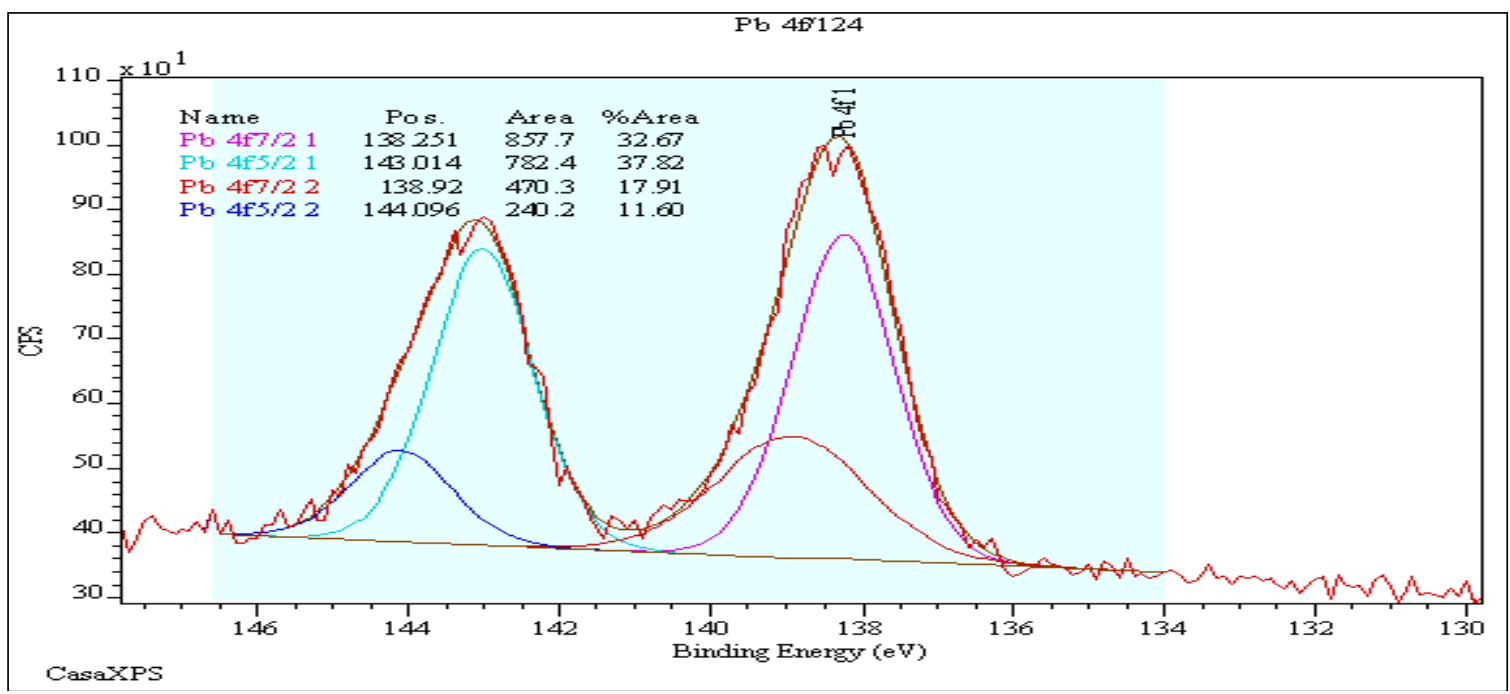

\section{5-Conclusions}

The XPS results suggests the formation of $\mathrm{PbSO}_{3}$ and $\mathrm{PbSO}_{4}$. The Raman results; suggests formation of $\mathrm{Pb}-\mathrm{Ca}-\mathrm{O}$ or $\mathrm{Pb}-\mathrm{SO}_{3}, \mathrm{~Pb}-\mathrm{Ca}-\mathrm{SO}_{4}$. The FTIR results suggest the formation of $\mathrm{PbCO}_{3}$ whereas the main compounds identified by the XRD formed in the presence of lime are: $\mathrm{PbSiO}_{3}$, $\mathrm{Pb}_{2} \mathrm{SO}_{4}, \mathrm{PbCO}_{3}, \mathrm{PbCO}_{3}$ or $\mathrm{Pb}(\mathrm{OH})_{2}$. $\mathrm{CaO}$, and $\mathrm{CaCO}_{3}, \mathrm{Ca}(\mathrm{OH})_{2}$.

\section{Acknowledgements}

The author gratefully Acknowledge the technical staff at biomedical research centre in Sheffield hallam university UK for their help and support with using the chemical analysis techniques. Also the assistance of administrative staff at National Authority of sciences and Research technology -Tripoli- Libya

\section{References}

[1] Environmental Protection Agency (2009) "Technology Performance Review: Selecting and Using Solidification/Stabilization Treatment for Site Remediation." Office of Research and Development U. S. EPA, Cincinnati, OH 45268. EPA/600/R-09/148.

[2] Jing, C, Meng, X., and Korfiatis, G.P. (2004) "Lead leach ability in stabilized/solidified soil samples evaluated with different leaching tests". Journal of Hazard Material. Vol.114: pages.101110. 
[3] Mickey, J.H., Thomas, H.R., Willims, K.P. and Ried, J.M. (2001). "Chemical analysis of contaminated soil strength by the addition of lime". Journal of Engineering Ecology Vol.60: pp.181192.

[4] Hassan, M, Gardiner, PHE, Khatib, J M, Mangat, PS (2012) "Stabilisation of Lead Contaminated Soil Using Portland Cement", International Workshop on Earthquake and Sustainable Materials, Sakarya University, Faculty of Technology, Civil Engineering Department, Turkey, pages 157-167, ISBN: 978-975-7988-92-2 XRD

[5] Hassan, M, Gardiner, PHE, Khatib, J M, Mangat, Nasef A (2013) FTIR and characterized lime stabilized lead contaminated soil. 2nd International Conference on Environment, Chemistry and Biology (ICECB 2013) in Stockholm, =Sweden, during December 13-14, http://www.cbees.org , http://www.icecb.org/.

[6] Barnett, S.J., Macphee, D.E., Lachowski, E.E. and Crammond N.J. (2002) "XRD, EDX and IR analysis of solid solutions between thaumasite and ettringite". Cement and Concrete Res. Vol.32: pages.719-730.

[7] Lopez-Lara, T. Hernández Zaragoza, López-Cajun (2004). "Mineralogical characterization of stabilized soils" Santiago de Querétaro, Querétaro, México, the Internet Geotechnical Engineering Magazine. Vol.9, (http://www.ejge.com/2004/Ppr0467/Ppr0467.htm

[8] Cardo's, F.A. ET AL. (2009)'Carbide lime and industrial hydrated lime characterization' Powder Technology vol. 195, pages $143-149$.

[9] Kirkpatrick, R.J. and Yarger, J.L. (1997) Raman Spectroscopy of C-S-H Tobermorite and Jennite. Advanced Cem. Base Mat.Vol.5: pp.93-99.

[10] Gibbs, P.J. (2010) http://www.chem.ucl.ac.uk/resources/raman/index.html. University College London - Department of Chemistry Copyright (C) 1999-2010 UCL.

[11] James, J.J., Cameron, R., and Baskcomb, C. (2008) Selected area XPS analysis for identification of pigment compounds in microscopic paint flakes. Research Letters in Materials Science.Vol.2008, pp1-4.

[12] Daeik Kim, Michael Quinlan, Teh Fu Yen (2009) Encapsulation of lead from hazardous CRT glass wastes using biopolymer cross-linked concrete systems. Waste Management.Vol.29: pp.321328.

[13] Tyczkowski, J. and Pietrzyk, B. (1998). Hydrogenated carbon-lead films plasma-deposited from tetraethyl lead in a three-electrode reactor. Chem. Mater., Vol.10: pp.3879-3887. 